\title{
Microbial Assay of Otamiri River and Its Sediments in Parts of Owerri
}

\section{Victor Inumidun Fagorite1, Cosmas Ahamefula Ahiarakwem¹, Sabinus Ikechukwu Ibeneme1, Ekeoma Sandra Chinemelu², Judith Ifeanyi Ukwajiunor ${ }^{3}$, Chidimma Maria Abiahu', John Olalekan Poopola ${ }^{1}$}

\author{
${ }^{1}$ Department of Geology, Federal University of Technology, Owerri, Nigeria \\ ${ }^{2}$ Department of Geology, Federal University of Petroleum Resources, Effurun, Nigeria \\ ${ }^{3}$ Department of Public Health, Federal University of Technology, Owerri, Nigeria \\ Email: fagorite@gmail.com
}

How to cite this paper: Fagorite, V. I.., Ahiarakwem, C. A., Ibeneme, S. I., Chinemelu, E. S., Ukwajiunor, J. I., Abiahu, C. M., \& Poopola, J. O. (2019). Microbial Assay of Otamiri River and Its Sediments in Parts of Owerri. Journal of Geoscience and Environment Protection, 7, 155-166. https://doi.org/10.4236/gep.2019.78011

Received: June 17, 2019

Accepted: August 16, 2019

Published: August 19, 2019

Copyright $\odot 2019$ by author(s) and Scientific Research Publishing Inc. This work is licensed under the Creative Commons Attribution International License (CC BY 4.0).

http://creativecommons.org/licenses/by/4.0/

\begin{abstract}
The aim of the study was to analyse and identify microbial constituents in the water and sediment samples with comparison of the River to World Health Organisation (WHO, 2011) standard for drinking water and Federal Ministry of Environment (FME, 2006) and their public health implications with respect to water quality. The microbial assay of Otamiri River was investigated using Standard plate count. The result indicates that microbial constituents of Otamiri river obtained at five strategic gauge stations designated SSWS 1 (Eg$\mathrm{bu}$ ), SSWS $_{2}$ (Timber Market), SSWS 3 (FUTO), DOWNSTREAM (Mbirichi) and CONTROL POINT with mean Total coliform Count of $3.0 \times 10^{2}, 3.0 \times$ $10^{3}, 4.1 \times 10^{3}$ and $1.0 \times 10^{3} \mathrm{cfu} / 100 \mathrm{ml}$ with control point value of $0.5 \times 10^{3}$ respectively. The mean Total Bacteria Count was $3.0 \times 10^{4}, 2.1 \times 10^{3}, 1.1 \times 10^{3}$ and $0.8 \times 10^{3} \mathrm{cfu} / 100 \mathrm{ml}$ respectively with control point value of $0.2 \times 10^{3}$ while the mean values for Total E. coli Count were $1.1 \times 10^{2}, 3.0 \times 10^{2}, 4 \times 10^{3}$ and $2.0 \times 10^{3} \mathrm{cfu} / 100 \mathrm{ml}$ with control point value of $0.2 \times 10^{3}$. The biochemical identification of some organisms in water was Escherichia coli, Vibro spp., Klebsiella spp., and Entrobacteria spp. The result of stream sediment samples indicates that the mean Total Bacterial Count was $3.5 \times 10^{4}, 5.0 \times 10^{4}, 6.5 \times$ $10^{4}$ and $2.0 \times 10^{4} \mathrm{cfu} / \mathrm{g}$ respectively with $1.5 \times 10^{2}$ as control point value and that of Total Coliform Count was $6.5 \times 10^{3}, 2.0 \times 10^{3}, 2.5 \times 10^{3}$ and $0.8 \times 10^{3}$ $\mathrm{cfu} / \mathrm{g}$ respectively with control point value of $0.5 \times 10^{2}$. While for the Total $E$. coli Count, the values were $2.5 \times 10^{3}, 1.0 \times 10^{3}, 2.5 \times 10^{3}$ and $0.5 \times 10^{5} \mathrm{cfu} / \mathrm{g}$ respective with control as $0.5 \times 10^{2}$. Biochemical identification of some organisms in sediments includes: Escherichia coli, Vibro spp., Klebsiella spp., Entrobacteria spp. and Bacillus spp. The mean total bacterial count, total coli form count and total E. coli, were not in conformity with both World Health
\end{abstract}


Organisation (WHO, 2011) Standard for drinking water and Federal Ministry of Environment (FME) 2006 standard for soil and thus constitute a threat to the River; these are attributed to waste dumps and anthropogenic activities around the five stations. The presence of bacteria in water can cause cholera, hepatitis, dysentery and typhoid. The microbial constituents can be reduced by chlorination.

\section{Keywords}

Coliforms, E. coli, Bacteria, Otamiri River, Sediments and Chlorination

\section{Introduction}

Water pollution is a major problem globally. It has been suggested that it is the leading worldwide cause of deaths and diseases and that it accounts for the deaths of more than 14,000 people daily (Mgbemena et al., 2012). Water pollution describes the presence of materials in water that interferes unreasonably with one or more beneficial uses of water (Akhionbare, 2009). Water pollution, especially surface water, can be caused by mining, recreational and agricultural activities. Agents of surface water pollution include bacteria, viruses and other substances present in such concentration or numbers to impair the quality of the water rendering it less suitable or unsuitable for its intended use and presenting a hazard to man or to his environment (Egereonu \& Ibe, 1999; Egereonu et al., 2012).

The Otamiri River is a major fresh surface water resource of South-eastern Nigeria. The river takes its name from "Otamiri”, a deity who owns all the water that is called by its name, and who is often the dominating god of Mban houses (Ihenyen \& Aghimien, 2002; Fagorite et al., 2019). It is located on latitude $5^{\circ} 23^{\prime} \mathrm{N}$ and $5^{\circ} 30^{\prime} \mathrm{N}$, and Longitude $6^{\circ} 58^{\prime} \mathrm{E}$ and $7^{\circ} 04^{\prime} \mathrm{E}$ (Figure 1 ). The river runs south from Egbu (its source) pass Owerri and through Nekede, Ihiagwa, Eziobodo, Obowuumuisu, Mgbirichi and Umuagwo (all in Imo state) to Ozuzu in Etche Local Government Area of Rivers state where it has a confluence with Oramirukwa River; both rivers flow from there into the Atlantic Ocean (Fagorite et al., 2019). According to Fagorite et al. (2019), Otamiri River is used for domestic, industrial and agricultural activities. The stream sediments on the river are used for various construction purposes. The quality of the river is exposed to threat from indiscriminate waste disposal, fishing, oil and natural gas activities to mention a few. Therefore, constant monitoring of the quality of surface water cannot be overstressed especially now that increase in population has resulted in generation of more waste thus exposing the water to more pollutants (Fagorite et al., 2019).

The aim of the study was to analyse and identify microbial constituents in the water and sediment samples with comparison of the River to World Health Organisation (WHO, 2011) standard for drinking water and Federal Ministry of 


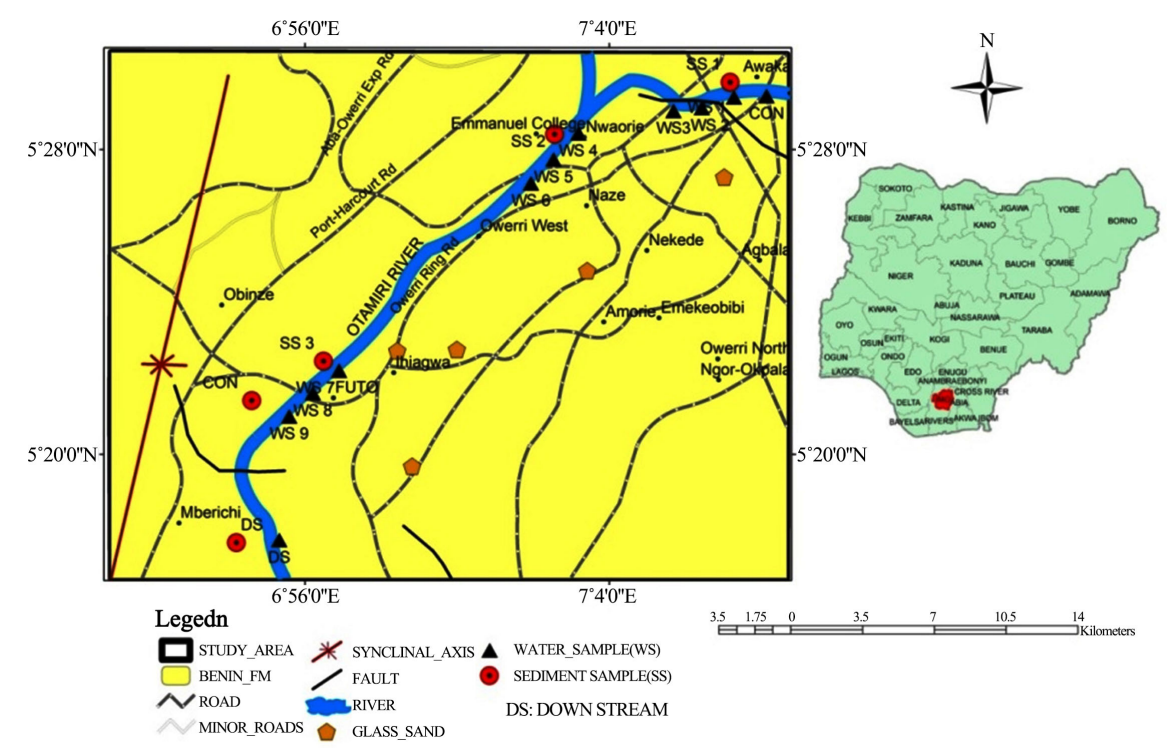

Figure 1. Geologic map of the study area.

Environment (FME, 2006) of the River and their public health implications. Recent studies on Otamiri River have been basically limited to just the water quality without relation with the sediment. Such study includes that of (Adieze et al., 2016), in which the effect of untreated sewage effluents on the water quality was investigated. Another study in India by Kora et al. (2017), on the water quality both physico-chemically and bacteriological parameters of Hussain Sagar lake. But the present study identified and analysed both water samples and sediment samples for microbial constituents in Otamiri River.

\section{Geology and Hydrogeology of the Study Area}

The geology of the area shows that it is underlain by the Benin Formation (Figure 1) which is an extensive stratigraphic unit in Southern Nigeria. The Benin Formation has variable thickness. It is underlain on land by the Oligocene-Miocene Ogwashi-Asaba Formation; on the subsurface by the petroleum bearing Agbada and Akata Formations (Ananaba et al., 1993). The Benin sands and sandstones are mainly deposits of continental upper deltaic plain environment. It is predominantly sandy with few shale intercalations becoming more abundant towards the base. The sands and sandstone are coarse grained pebbles, sub angular to well rounded and whitish or yellowish in colour probably because of limonite coating and bears lignite streaks and wood fragments (Ananaba et al., 1993). The sands may represent point bar deposits, channel fills or natural levees whereas the shales may be interpreted as back swamp deposits and oxbow fills. The thickness of the formation is variable and may be more than $1800 \mathrm{~m}$.

\section{Methodology}

\subsection{Sample Collection}

Eleven water samples were obtained along the stretch of the Otamiri River at five 
strategic stations designated $\mathrm{SSWS}_{1}$ (Egbu), $\mathrm{SSWS}_{2}$ (Timber Market), $\mathrm{SSWS}_{3}$ (FUTO), DOWNSTREAM (Mbirichi) and CONTROL POINT using grab method Figure 2; the water samples were geo-referenced. Land use elements especially waste dump sites were visited and examined. Samples were taken at a distance of 300 meters and collected with the aid of sterilized 1.5 litres plastic containers. The samples were corked under water immediately after collection so as to avoid the oxidation of the constituents and later sent to the laboratory within 24 hours for analysis. Water samples collected from these sampling stations were analysed in accordance with the American Public Health Association (APHA) standard methods for examination of water and wastewater (APHA, 2012). The stream sediments were obtained at 5 strategic locations using manual dredging method Figure 2. The samples were collected into black polyethene bags and sent to the laboratory for analysis within 24 hours.

\subsection{Laboratory Analysis}

Serial dilution of the water samples were carried out using sterile distilled water as in (Chessbrough, 2002). The water and sediment samples were examined bacteriologically using culture techniques as in (Chessbrough, 2002). Each water sample was examined by culture technique using streak plate and spread plate technique Figure 3. A sterile wire loop was used to collect a loop full of each undiluted water sample and inoculated on the surface of nutrient agar, blood agar,

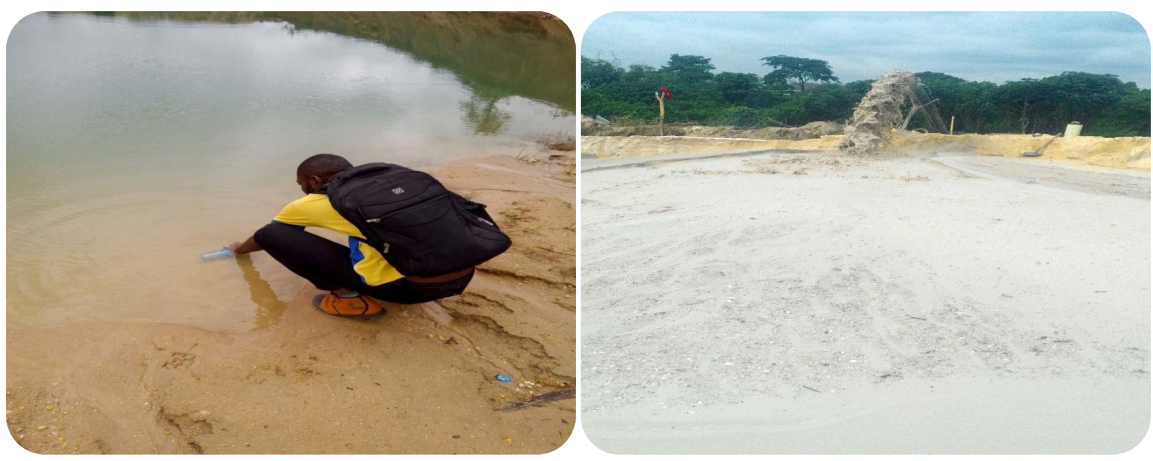

Figure 2. The grab method for water collection and collection of sediment through manual dredging.

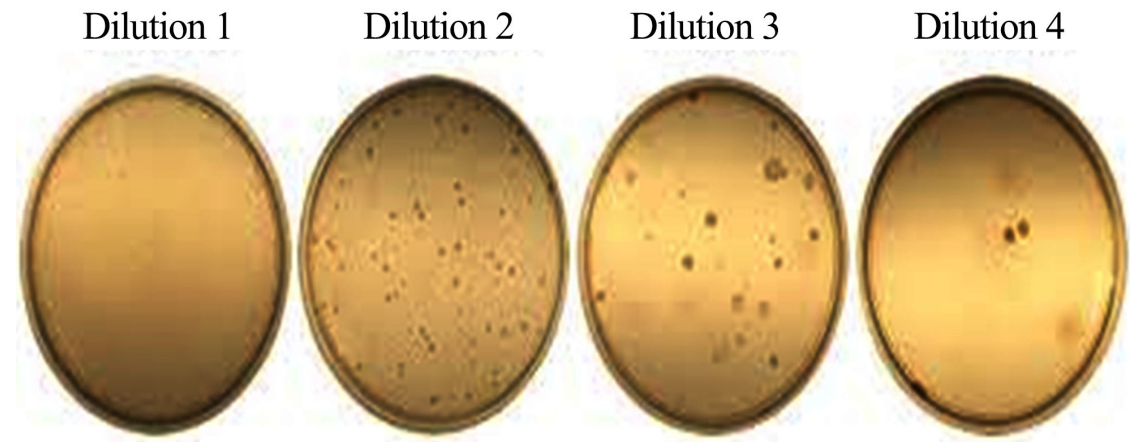

Figure 3. Standard plate method (Source: Wikipedia, 2019). 
MacConkey agar and Eosine Methylene Blue agar (Mgbemena et al., 2012). The inoculated plates were subsequently sub-cultured on fresh nutrient agar, MacConkey agar and blood agar plates to obtain pure cultures as well as study their morphological characteristics. They were incubated at $37^{\circ} \mathrm{C}$ for $24 \mathrm{~h}$. The pure culture isolates were sub-cultured in nutrient agar slant and incubated at $37^{\circ} \mathrm{C}$ for $24 \mathrm{~h}$ and were then stored in the refrigerator until required for further use. All the different dilutions were properly labelled and used for total plate count. The bacteria isolates were subjected to various tests beginning from the study of their growth morphology on different agar media to different microbiological identification tests such as gram staining and motility tests and biochemical identification tests such as catalase, coagulase, oxidase, citrate utilization, urease, indole production, hydrogen sulphide production, nitrate and nitrite reduction, methyl red, Voges Proskeur and sugar fermentation tests (Table 5 and Table 6).

\subsection{Parameters and Materials Used (Table 1 and Table 2)}

Table 1. Materials ranging from the field tools, laboratory tools, reagents and software used.

\begin{tabular}{|c|c|}
\hline Parameters & Materials \\
\hline $\begin{array}{l}\text { Total bacteria } \\
\text { count, } \mathrm{cfu} / \mathrm{ml}\end{array}$ & $\begin{array}{l}\text { Nutrient agar medium (Peptone } 5 \mathrm{~g} / \mathrm{L}, \mathrm{NaCl} 5 \mathrm{~g} / \mathrm{L} \text {, beef extract } 1.5 \mathrm{~g} / \mathrm{L} \text {, yeast } \\
\text { extract } 1.5 \mathrm{~g} / \mathrm{L} \text {, agar } 15 \mathrm{~g} / \mathrm{L}, \mathrm{pH} 7.4 \text { ) }\end{array}$ \\
\hline Total Coliform & Selective medium HiCrome coliform agar (Peptone $3 \mathrm{~g} / \mathrm{L}, \mathrm{NaCl} 5 \mathrm{~g} / \mathrm{L}$, \\
\hline Count, $\mathrm{cfu} / \mathrm{ml}$ & dipotassium hydrogen phosphate $3 \mathrm{~g} / \mathrm{L}$, potassium dihydrogen phosphate \\
\hline and Total E. coli & $1.7 \mathrm{~g} / \mathrm{L}$, sodium pyruvate $1 \mathrm{~g} / \mathrm{L}, 1$-tryptophan $1 \mathrm{~g} / \mathrm{L}$, sodium lauryl sulphate \\
\hline Count, $\mathrm{cfu} / \mathrm{ml}$ & $0.1 \mathrm{~g} / \mathrm{L}$, chromogenic mixture $0.2 \mathrm{~g} / \mathrm{L}$, agar $15 \mathrm{~g} / \mathrm{L}, \mathrm{pH} 6.8)$ \\
\hline
\end{tabular}

Table 2. Materials ranging from the field tools, laboratory tools, reagents and software used.

\begin{tabular}{lllll}
\hline S/N & Field Tools & Laboratory Tools & Reagents & Softwares Used \\
\hline 1 & Topographic map & pH meter & $\begin{array}{l}\text { Sabourand } \\
\text { Dextrose Agar }\end{array}$ & Microsoft word and excel \\
2 & $\begin{array}{l}\text { Global positioning } \\
\text { system (E-Trex GPS) }\end{array}$ & Glass ware & Nutrient agar & \\
3 & $\begin{array}{l}\text { Sample bottles and } \\
\text { sample bags }\end{array}$ & $\begin{array}{l}\text { Hanna Hi 83200 } \\
\text { photometer }\end{array}$ & Distilled Water \\
4 & & Hox box oven & Mineral Salts \\
& & Agar (medium) \\
5 & & Burrette & Nitric acid \\
6 & Cornical flask & Perchloric acid \\
7 & Pipettes & Sulphuric acid \\
8 & & Crucibles & Air oxidant gas \\
9. & Incubator & \\
10. & Autoclave & \\
11. & Burnsen burner & \\
\hline
\end{tabular}




\subsection{Method of Result Analysis}

The average mean of three samples per station $\left(\mathrm{SSWS}_{1}-\mathrm{SSWS}_{2}\right)$ was taken for three stations and one the reading for the remaining two stations (Control and Downstream). The results obtained were compared with World Health Organization (WHO, 2011) standard for drinking water while Federal Ministry of Environment (FME, 2006) was used for the sediment.

\section{Results and Discussion}

The mean Total Bacteria Counts of the Otamiri River at SSWS ${ }_{1}, \mathrm{SSWS}_{2}, \mathrm{SSWS}_{3}$ and Downstream stations were $3.0 \times 10^{4}, 2.1 \times 10^{3}, 1.1 \times 10^{3}$ and $0.8 \times 10^{3}$ $\mathrm{cfu} / 100 \mathrm{ml}$ respectively with control point value of $0.2 \times 10^{3} \mathrm{cfu} / 100 \mathrm{ml}$. From the values indicated for Total Bacteria Count, it reveals that SSWS $(\mathrm{Egbu})$ was with the highest value. While the mean Total Coliform Count were $3.1 \times 10^{2}, 3.0$ $\times 10^{3}, 4.1 \times 10^{3}$ and $1.0 \times 10^{3} \mathrm{cfu} / 100 \mathrm{ml}$ respectively with control point value of $0.5 \times 10^{3} \mathrm{cfu} / 100 \mathrm{ml}$. The value of SSWS 3 (FUTO) was the highest with respect to this parameter which is due to heavy activity within such as effluent disposal the school area (Adieze et al., 2016). The Total E. coli. Count were $1.1 \times 10^{2}, 3.0 \times$ $10^{2}, 4.0 \times 10^{3}$ and $2.0 \times 10^{3} \mathrm{cfu} / 100 \mathrm{ml}$ (Table 4) with control point value of $0.2 \times$

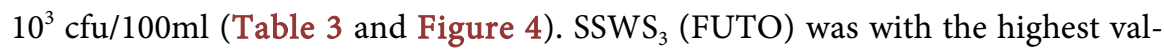
ue. Feresu \& Vansickle (1990) recorded between $1.8 \times 10^{3} \mathrm{CFU} / 100 \mathrm{ml}$ and $3.3 \times$ $10^{4} \mathrm{CFU} / 100 \mathrm{ml}$ coliforms in Zambezi River receiving untreated sewage effluents. This agrees with the work of (Rheinheimer, 1991) which reported that the introduction of wastewater high in organic matter and essential nutrients bring about changes in the micro flora (Adieze et al., 2016). It was also observed that high counts of bacterial load reflected the level of water pollution as it gives indication of the amount of organic matter present (Anson \& Ware, 1974; Adieze et al., 2016) (Table 4).

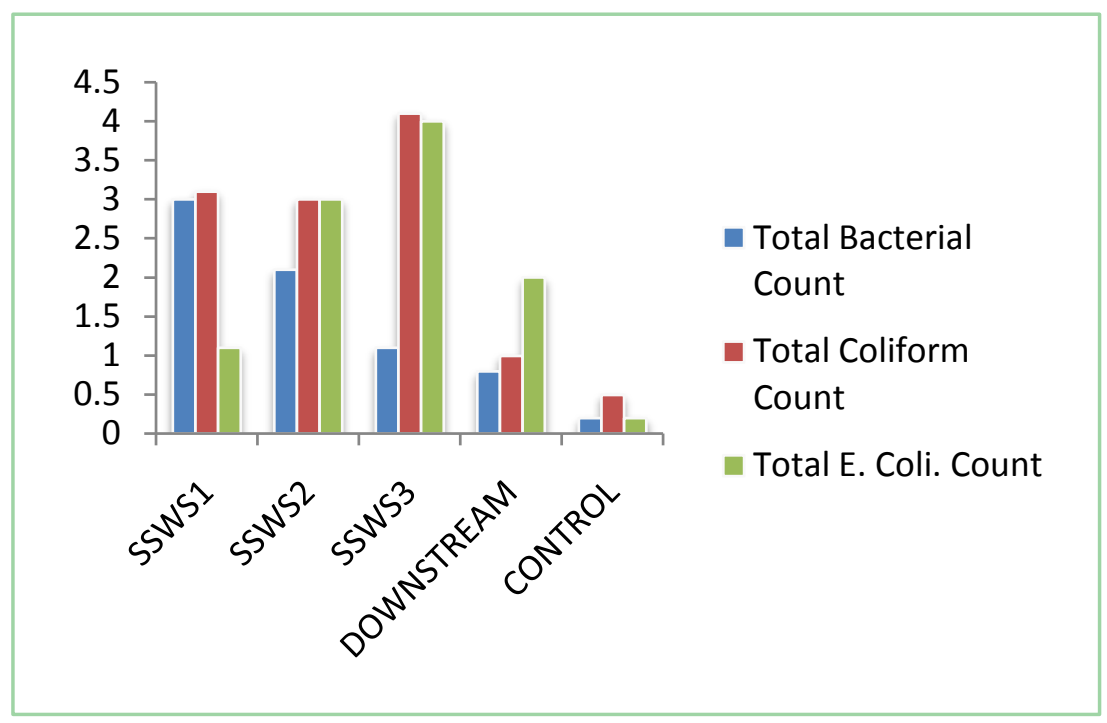

Figure 4. Microbial counts in water. 
Table 3. Most probable organisms of water samples Otamiri River per stations.

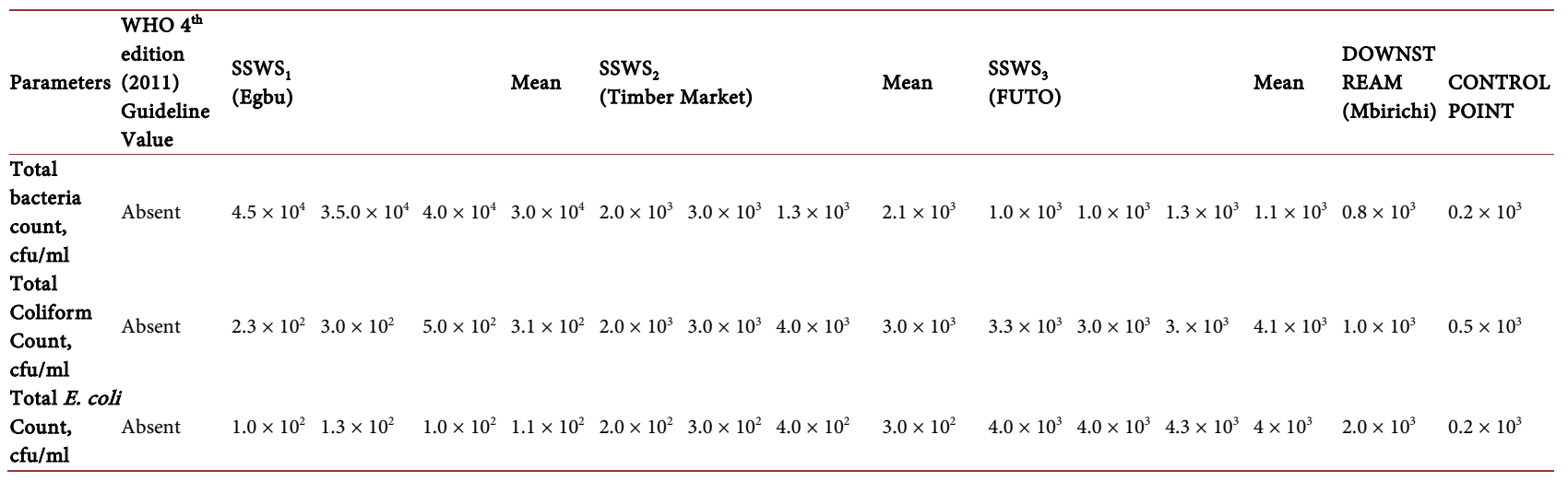

Table 4. Most probable organisms in sediment samples per stations from Otamiri River.

\begin{tabular}{ccccccc}
\hline Parameters & FME Standard 2006 & SSWS $_{1}$ & SSWS $_{2}$ & SSWS $_{3}$ & DOWNSTREAM CONTROL POINT \\
\hline $\begin{array}{c}\text { Total Bacteria } \\
\text { Count, cfu/g }\end{array}$ & NS & $3.5 \times 10^{4}$ & $5.0 \times 10^{4}$ & $6.5 \times 10^{4}$ & $2.0 \times 10^{4}$ & $1.5 \times 10^{2}$ \\
$\begin{array}{c}\text { Total Coliform } \\
\text { Count, cfu/g }\end{array}$ & NS & $6.4 \times 10^{3}$ & $2.0 \times 10^{3}$ & $2.5 \times 10^{3}$ & $0.8 \times 10^{3}$ & $0.5 \times 10^{2}$ \\
$\begin{array}{l}\text { Total } E . \text { coli } \\
\text { Count, cfu/g }\end{array}$ & NS & $2.0 \times 10^{3}$ & $1.0 \times 10^{3}$ & $1.1 \times 10^{3}$ & $0.5 \times 10^{3}$ & $0.5 \times 10^{2}$ \\
\hline
\end{tabular}

Key: SSWS $_{1}$-Egbu, SSWS 2 -Timber Market, SSWS $_{3}$-FUTO and DOWNSTREAM-Mbirichi WHO-World Health Organization (2011).

With respect to the sediments, the values for the Total Bacterial Count at SSWS $_{1}$, SSWS $_{2}$, SSWS $_{3}$ and Downstream station were $3.5 \times 10^{4}, 5.0 \times 10^{4}, 6.5 \times$ $10^{4}$ and $2.0 \times 10^{4} \mathrm{cfu} / \mathrm{g}$ respectively with control point value of $1.5 \times 10^{2} \mathrm{cfu} / \mathrm{g}$. $\mathrm{SSWS}_{3}$ (FUTO) was with the highest value again just as in the case of the water samples which is due to heavy activities within the school environment such as sewage disposal and defecation Figure 5. The Total Coliform Count was $6.5 \times$ $10^{3}, 2.0 \times 10^{3}, 2.5 \times 10^{3}$ and $0.8 \times 10^{3} \mathrm{cfu} / \mathrm{g}$ with a control point value of $0.5 \times 10^{2}$ $\mathrm{cfu} / \mathrm{g}$. SSWS $\mathrm{S}_{1}(\mathrm{Egbu})$ was with the highest value which is indicative of waste disposal within and around the station. For the Total $E$. Coli Count, the values were $2.5 \times 10^{3}, 1.0 \times 10^{3}, 2.5 \times 10^{3}$ and $0.5 \times 10^{3} \mathrm{cfu} / \mathrm{g}$ respectively with control point value of $0.5 \times 10^{2} \mathrm{cfu} / \mathrm{g}$. In as much there is no standard assigned for the microbial constituents, the values all exceed the control point value due to the fact that rivers have a self-purifying capacity (Adieze et al., 2016). Therefore, the microbial constituents tend to reduce along the stretch of the river from the source to downstream Table 4 and Figure 6.

Although the WHO guideline indicates no standard, their presence in water indicates faecal contamination of the water. Escherichia coli, an indicator of these enterobacteria in water is harmless but the others have been implicated as the causative agent of one waterborne disease or the other (Duru et al., 2012). According to Ahiarakwem (2013), the indiscriminate disposal of diapers at dumpsites in addition to defecations within and around the watershed of the river is responsible for its poor microbial assay. The presence of bacteria in water can cause cholera, hepatitis, dysentery and typhoid (Ahiarakwem, 2013). 


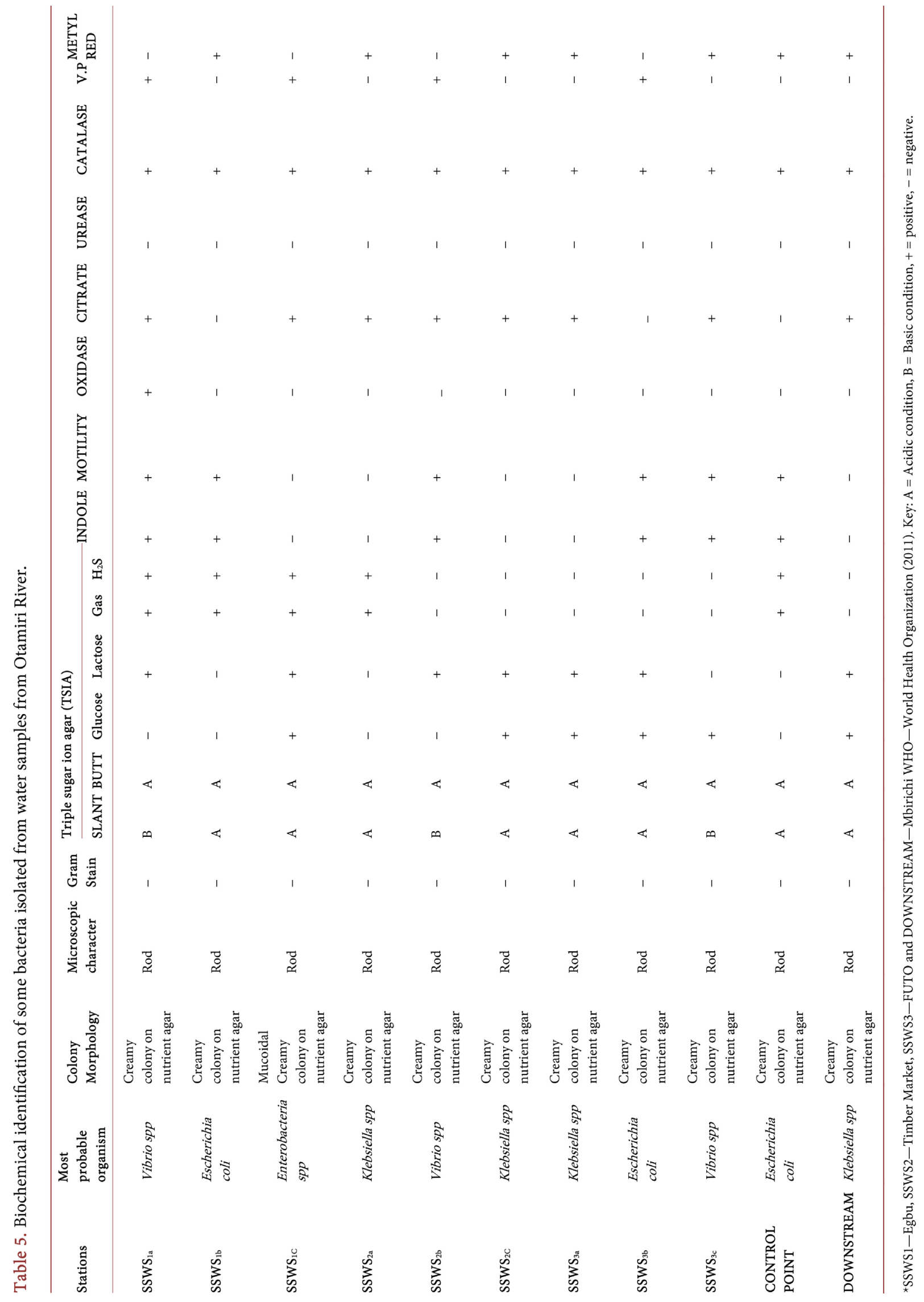




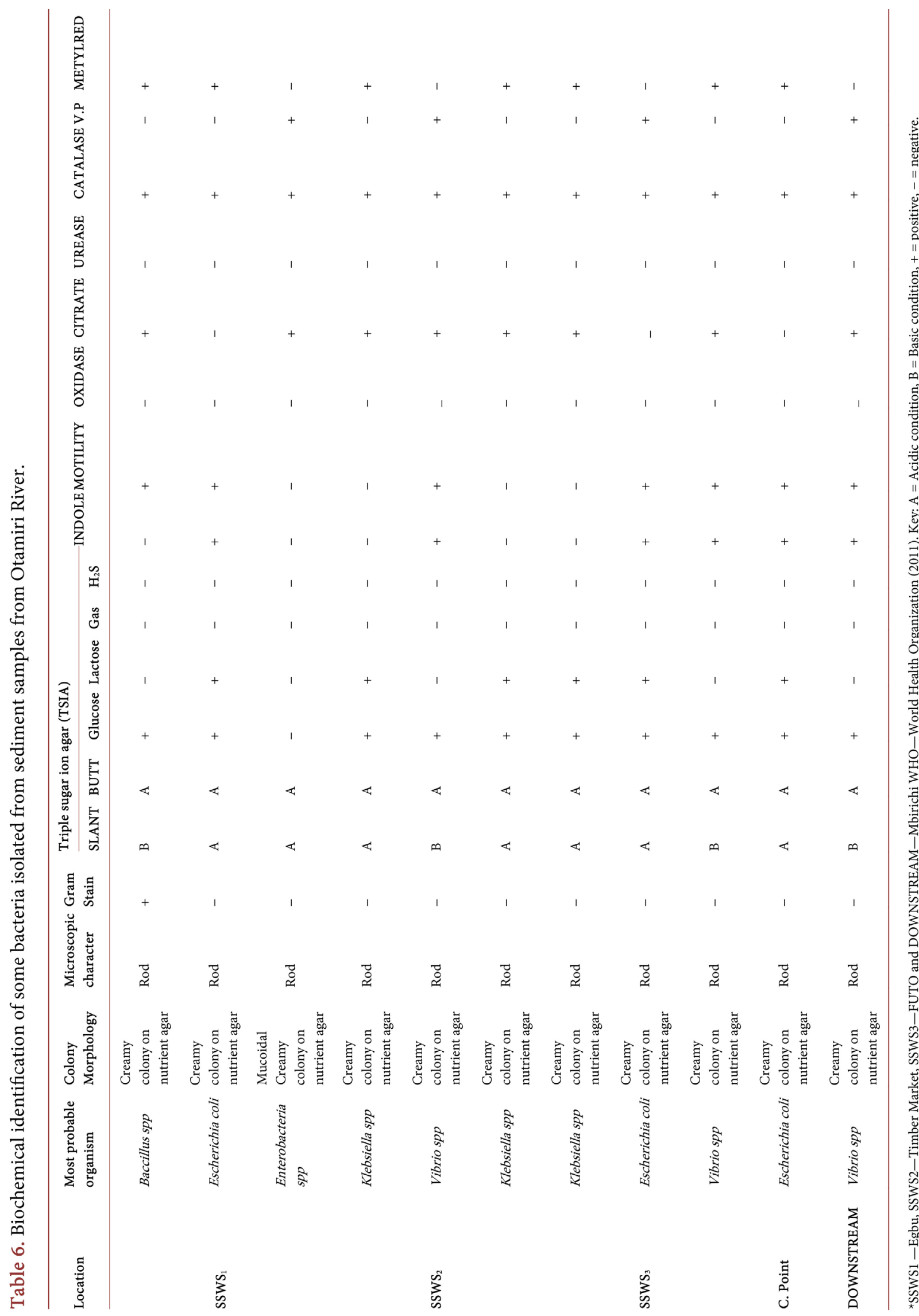



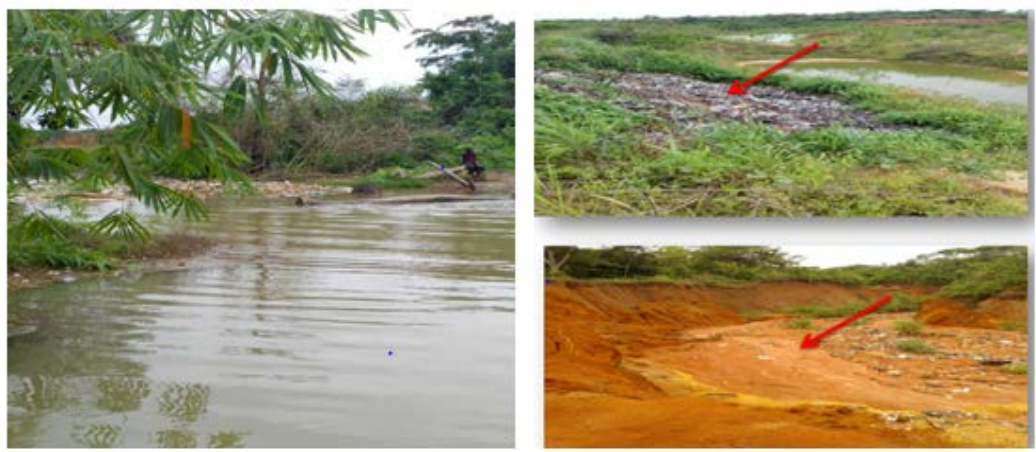

Figure 5. Landfill along the Otamiri River channel.

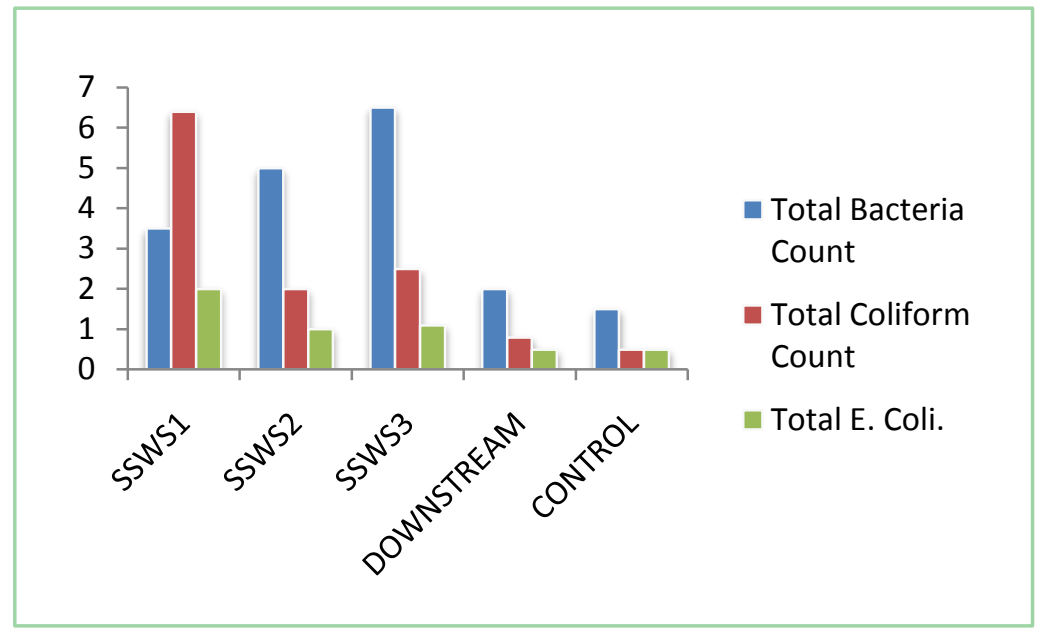

Figure 6. Microbial counts in sediment.

\section{Conclusion}

The Otamiri River at the Five stations $\left(\mathrm{SSWS}_{1}, \mathrm{SSWS}_{2}, \mathrm{SSWS}_{3}\right.$, Downstream and Control Point) is polluted with microbial constituents (bacteria such as: Escherichia coli, Vibro spp., Klebsiella spp., and Entrobacteria spp.). For the sediment, it shows pollution with respect to microbial constituents (bacteria such as: Escherichia coli, Vibro spp., Klebsiella spp., Entrobacteria spp. and Bacillus spp.). These pollutants are attributed to the waste and effluents disposed from land of the five stations. This calls for proper waste management practices and pre-use treatment of the river water with chlorine as well as boiling before usage in order to reduce the microbial constituents of the water. Therefore, there is a need for constant monitoring of the microbial characteristics of the river. In addition, communities along the river bank need to ensure that untreated wastes are not disposed of improperly on land where it can be washed into the river. This work focused primarily on the sediments of the river. Therefore, subsequent research should be centered on the collection of samples per depth at other strategic locations of concern with respect to seasons. This is due to the over dredging of sands from the river which has resulted in erosion and sinkholes around the river. 


\section{Acknowledgements}

I am most grateful to God Almighty for His love, divine inspiration and infinite mercy. I acknowledge all staff both teaching and none teaching, of Geology Department Federal University Technology, Owerri, for the concern shown all through this study. Lastly, I appreciate my parents, Pastor Francis Oloruntobi Fagorite JP and Deaconess Faith Kehinde Fagorite for their deep support morally and financially.

\section{Conflicts of Interest}

The authors declare no conflicts of interest regarding the publication of this paper.

\section{References}

Adieze, I. E., Nwosu, C. I., Adieze, N. C., \& Nwabueze, R. N. (2016). Effects of Untreated Sewage Effluent on the Water Quality of Otamiri River in Owerri. Nigerian Journal of Microbiology, 30, 3241-3245.

Ahiarakwem, C. A. (2013). The Impacts of Njoku Sawmill Landfill on the Water Quality of the Otamiri River, Owerri Metropolis, Niger Delta Basin, Southeastern Nigeria. International Journal of Engineering Inventions, 2, 26-34. http://www.ijeijournal.com

Akhionbare, S. M. O. (2009). Concepts, Issues \& Control of Pollution (p. 82). Nnewi: MC Computers Press.

Ananaba, S. E., Onu, N. N., \& Iwuagwu, C. J. A. (1993). Geophysical Study of the Gravel Deposits in Ihiagwa, Owerri, Nigeria. Journal of Mining Geology, 29, 95-100.

Anson, A. E., \& Ware, G. C. (1974). Survey of Distribution of Bacterial Pollution in the Bristol Channel. Journal of Applied Bacteriology, 37, 657-661. https://doi.org/10.1111/j.1365-2672.1974.tb00490.x

APHA (American Public Health Association) (2012). Standard Methods for the Examination of Water and Wastewater (22nd ed.). Washington DC: American Public Health Association.

Chessbrough, M. (2002). Laboratory Manual for Tropical Countries. Vol. II. Microbiology ELBS. London: Tropical Health Technology and Butterworth.

Duru, M. K. C., Nwanekwu, K. E., Adindu, E. A., \& Odika, P. C. (2012). Heavy Metal and Bioload Levels of Otamiri River, Owerri, Imo State, Nigeria. Scholars Research Library Archives of Applied Science Research, 4, 1002-1006.

Egereonu, U. U., \& Ibe, R. M. (1999). Ground Water Quality Investigations in the Niger Delta Area and Parts of the Eastern States of Nigeria. Environmental Analar, 4, 259-267.

Egereonu, U. U., Ukiwe, L. N., Edet, J. A., \& Ogukwe, C. E. (2012). Investigation of Pollution Index of Oramiriukwa, Nworie and Otamiri Rivers, Imo State, Nigeria. Journal of Chemical Society of Nigeria, 37, 25-29.

Fagorite, V. I., Ahiarakwem, C. A., Okeke, O. C., \& Onyekuru, S. O. (2019). Physico-Chemical Characteristics of Otamiri River and Its Sediments in Parts of Owerri Elixir Geology. Elixir International Journal, 131, 53223-53229. http://www.elixirpublishers.com

Feresu, S. B., \& Vansickle, J. (1990). Coliforms as a Measure of Sewage Contamination of the River Zambezi. Journal of Applied Bacteriology, 68, 397-403. 
https://doi.org/10.1111/j.1365-2672.1990.tb02890.x

Ihenyen, A. E., \& Aghimien, A. E. (2002). A Study of Trace Heavy Metal Levels in Warri Soils and Vegetables, Southern Nigeria. African Journal of Environmental Pollution Health, 1, 72-82.

Kora, A. J., Rastogia, L., Kumara, S. J., \& Jagatap, B. N. (2017). Physico-Chemical and Bacteriological Screening of Hussain Sagar Lake: An Urban Wetland. Water Science Direct, 31, 24-33. http://www.elsevier.com/locate/wsj https://doi.org/10.1016/j.wsj.2017.03.003

Mgbemena, I. C., Nnokwe, J. C., Adjeroh, L. A., \& Onyemekara, N. N. (2012). Resistance of Bacteria Isolated from Otamiri River to Heavy Metals and Some Selected Antibiotics. Current Research Journal of Biological Sciences, 4, 551-556.

Rheinheimer, G. (1991). Aquatic Microbiology (4th ed., p. 363). New York: John Wiley and Sons.

WHO (2011). Guidelines for Drinking-Water Quality (4th ed., pp. 155-202). Geneva: WHO.

Wikipedia (2019). Standard Plate Methods. https://iied21.hccs.edu/JyotiW/BiologyLabs/Micro/04CountingBacteria/SPC_milk_Qui z/mobile_pages/index.html 